\title{
Size-dependent photosynthetic variability in the North Pacific Subtropical Gyre
}

\author{
Binglin Li ${ }^{1}$, David M. Karl ${ }^{1}$, Ricardo M. Letelier ${ }^{2}$, Matthew J. Church ${ }^{1, *}$ \\ ${ }^{1}$ Department of Oceanography, University of Hawaii, 1000 Pope Road, Honolulu, Hawaii 96822, USA \\ ${ }^{2}$ College of Oceanic and Atmospheric Sciences, Oregon State University, 104 COAS Administration Building, Corvallis, \\ Oregon 97331, USA
}

\begin{abstract}
Photosynthesis-irradiance $(P-E)$ relationships and in situ measurements of primary production for 2 phytoplankton size fractions ( $>2 \mu \mathrm{m}$ and 0.2 to $2 \mu \mathrm{m}$ ) were used to evaluate variability in photophysiology over a 5 yr period (2004 to 2009) in the North Pacific Subtropical Gyre (NPSG). Picophytoplankton ( 0.2 to $2 \mu \mathrm{m}$ ) were dominant contributors to euphotic zone chlorophyll a (chl a) concentrations (averaging $91 \pm 2 \%$ [mean $\pm \mathrm{SD}$ ] of the 0 to $125 \mathrm{~m}$ depth-integrated inventories) and accounted for a major fraction (averaging $74 \pm 7 \%$ ) of the in situ, depth-integrated, ${ }^{14} \mathrm{C}$ based primary production. Short-term in vitro $P$-E experiments were conducted to examine the photophysiology of both phytoplankton size classes. Results from these experiments demonstrated that in the well-lit ocean $(0$ to $45 \mathrm{~m}) \mathrm{chl}$ a normalized maximum rates of photosynthesis, $P_{\text {max }}^{\mathrm{chl}}$ were significantly greater among the larger phytoplankton size class than in the smaller size fraction (1-way ANOVA, p < 0.01), while in the dimly lit region $(125 \mathrm{~m})$ there were no significant sizedependent differences in $P_{\text {max }}^{\mathrm{chl}}$ (1-way ANOVA, $\left.\mathrm{p}>0.05\right)$. Neither the initial slope of the $P$-E relationships, $\alpha$, nor the light intensities required to saturate photosynthesis, $E_{k}$, varied significantly between the 2 size fractions. Although larger phytoplankton appear to constitute a relatively small fraction of phytoplankton biomass and production in this ecosystem, the photophysiological responses of plankton in this size class demonstrated considerable variability, suggesting these larger size phytoplankton experience time-variable changes in growth despite persistently oligotrophic habitat conditions.
\end{abstract}

KEY WORDS: Photosynthesis · Photophysiology $\cdot$ Phytoplankton · Primary production North Pacific $\cdot$ Oligotrophic

\section{INTRODUCTION}

Organic matter production by photosynthetic plankton constitutes a major control on the cycling of elements in the sea. Marine primary productivity accounts for nearly half of net global carbon fixation, and a major fraction of this productivity occurs in the low nutrient waters of the subtropical ocean gyres (Longhurst et al. 1995, Karl et al. 1996, Falkowski et al. 1998, Field et al. 1998, Behrenfeld et al. 2005). As a result, understanding the processes controlling the physiologies of photosynthetic plankton in oligo- trophic gyres is critical to our understanding of the global carbon cycle.

The spatial and temporal patterns of primary production and the photophysiology of ocean phytoplankton have been intensively investigated (e.g. Platt et al. 1982, Sakshaug \& Holm-Hansen 1986, Cullen et al. 1992, MacIntyre et al. 2002, Strzepek \& Harrison 2004, Falkowski \& Raven 2007). Such studies reveal that variations in phytoplankton physiology are reflected in characteristic patterns in the photosynthetic response to irradiance (Jassby \& Platt 1976, Falkowski \& Owens 1980, Platt et al. 1980). 
Photosynthesis-irradiance $(P-E)$ relationships demonstrate several well-defined characteristics, which are typically described by using hyperbolic or negative exponential models (Jassby \& Platt 1976, Platt et al. 1980). Various photophysiological parameters can be derived from such relationships, including the maximum rate of carbon fixation (termed $P_{\max }$ ), the initial slope (termed $\alpha$ ) of the $P-E$ response, which provides a measure of light harvesting efficiency by photosynthesis, the susceptibility of photosynthesis to inhibition at elevated light flux (termed $\beta$ ) and the irradiance required to saturate photosynthesis (termed $E_{k}$ ). When used in $P$-E relationships, rates of photosynthesis are frequently normalized to concentrations of chlorophyll a $(\operatorname{chl} a)$, where the resulting normalized maximum photosynthetic rate is termed $P_{\text {max. }}^{\text {chl }}$

When combined with information on temperaturedependent phytoplankton growth (Eppley 1972), P-E derived parameters can be incorporated into biooptical models and used to estimate areal rates of primary production from remotely sensed determinations of phytoplankton pigments, temperature and light (Bidigare et al. 1992, Platt \& Sathyendranath 1993, Behrenfeld \& Falkowski 1997). Moreover, analyses of the $P$-E derived behavior provides information on the photophysiological flexibility of phytoplankton in specific environments and can yield insight into controls underlying time and space variability in primary production (e.g. Harrison \& Platt 1980, Cullen 1990, Ondrusek et al. 2001, Goebel \& Kremer 2007, McAndrew et al. 2008, Isada et al. 2009). Most in situ studies aimed at characterizing rates of primary production and photosynthetic physiology are based on analyses of bulk phytoplankton metabolism and thus do not resolve the physiological variability that underpins rates of productivity. In this context, resolving how distinct phytoplankton size fractions contribute to inorganic carbon fixation and the photophysiological behaviors of different phytoplankton size fractions may be useful for understanding processes controlling production in the marine environment.

The North Pacific Subtropical Gyre (NPSG) is the largest anticyclonic circulation feature on Earth (Sverdrup et al. 1946) and forms the primary study region for the Hawaii Ocean Time-series (HOT) program. More than $22 \mathrm{yr}$ of observations at Station ALOHA $\left(22^{\circ} 45^{\prime} \mathrm{N}, 158^{\circ} 00^{\prime} \mathrm{W}\right)$, the field site for the HOT program, indicate moderate but consistent seasonal variations in environmental forcing, including properties that influence phytoplankton growth. For example, photosynthetically active radiation (PAR) at the surface varies approximately 2-fold seasonally, upper ocean temperatures fluctuate between 23 and $27^{\circ} \mathrm{C}$ and weak to moderate wintertime mixing combined with shoaling of the nutricline seasonally entrains nutrients into the euphotic zone (Karl et al. 2001, Letelier et al. 2004, Church et al. 2009). Several studies have examined seasonal to interannual scale changes in phytoplankton biomass and productivity in the NPSG and concluded that variability in phytoplankton community structure forms an important control on net production and carbon export in this ecosystem (Letelier et al. 1993, 1996, Winn et al. 1995, Karl et al. 1996, 2001, 2002, Dore et al. 2008). Moreover, a bio-optical model based on measured $P$-E relationships at Station ALOHA concluded that the model's ability to predict euphotic zone productivity could be improved through better understanding of how shifts in the phytoplankton community influence the measured photophysiological responses (Ondrusek et al. 2001). Fast-repetition-rate fluorometry (FRRF) has been used to characterize photosynthetic processes at Station ALOHA (Corno et al. 2008), and results from that study suggested that the dynamics underlying time-space variability in plankton photophysiology were sensitive to changes in plankton community structure.

These past studies on the photosynthetic characteristics of the phytoplankton community in the NPSG, which used different methods, suggest that changes in phytoplankton community structure play an important role in driving variability in ecosystem production. Picophytoplankton (0.2 to $2 \mu \mathrm{m})$, including cyanobacteria such as Prochlorococcus and Synechococcus, are dominant components of upper ocean plankton biomass in the NPSG (Campbell \& Vaulot 1993, Letelier et al. 1993, Andersen et al. 1996); however, the contributions of larger phytoplankton, including filamentous and colonial cyanobacteria and protists, appear to contribute to regularly occurring bloom events observed in this region (White et al. 2007, Dore et al. 2008, Fong et al. 2008, Church et al. 2009). These previous studies emphasize that changes in plankton composition in the NPSG are often accompanied by shifts in phytoplankton size structure. The present study sought to examine the temporal and vertical variation in photophysiological parameters (i.e. $P_{\text {max }}^{\text {chl }}, E_{k}$ and $\alpha$ ) of size-fractionated phytoplankton at Station ALOHA. Our goal was to assess time and depth variability underlying the photophysiology and productivity of different size-separated groups of phytoplankton in the NPSG. 


\section{MATERIALS AND METHODS}

\section{Chl $a$ and in situ measurements of ${ }^{14} \mathrm{C}$-bicarbonate assimilation}

Seawater samples for determinations of size partitioning of $\mathrm{chl}$ a concentrations and rates of ${ }^{14} \mathrm{C}$-bicarbonate assimilation were collected from 6 discrete depths in the upper ocean $(5,25,45,75,100$ and $125 \mathrm{~m}$ ) at Station ALOHA during near-monthly HOT program cruises between October 2004 and December 2009. Predawn samples were collected with a vertically profiling CTD rosette sampler equipped with twenty-four 101 PVC bottles.

In the initial $3 \mathrm{yr}$ of this study (October 2004 to October 2007), seawater for determinations of chl a concentrations was subsampled into $1 \mathrm{l}$ amber polyethylene bottles; the entire volume was sequentially filtered by positive pressure through in-line, $25 \mathrm{~mm}$ diameter, 10 and $2 \mu \mathrm{m}$ pore size, polycarbonate filters. The $2 \mu \mathrm{m}$ filtrate was collected and $150 \mathrm{ml}$ of this filtrate was vacuum-filtered onto $25 \mathrm{~mm}$ diameter, $0.2 \mu \mathrm{m}$ pore size, polycarbonate filters. Filters were placed in $7 \mathrm{ml}$ of $100 \%$ HPLC grade acetone and extracted in the dark at $-20^{\circ} \mathrm{C}$ for $7 \mathrm{~d}$ (Letelier et al. 1996). Concentrations of chl $a$ in the acetone extracts were determined fluorometrically by using a Turner Designs Model 10-AU fluorometer. In the second phase of this study (October 2007 to December 2009), coinciding with the period when $P-E$ experiments were conducted, chl a concentrations were determined from plankton concentrated onto $25 \mathrm{~mm}$ diameter, 2 and $0.2 \mu \mathrm{m}$ pore size, polycarbonate filters. For these measurements, $150 \mathrm{ml}$ of seawater was vacuum filtered onto both 2 and $0.2 \mu \mathrm{m}$ pore size polycarbonate filters and concentrations of chl a were determined fluorometrically. The chl a concentrations in the 0.2 to $2 \mu \mathrm{m}$ size fraction were calculated by subtracting the $>2 \mu \mathrm{m}$ chl $a$ from the $>0.2 \mu \mathrm{m} \mathrm{chl} \mathrm{a.} \mathrm{Comparison} \mathrm{of} \mathrm{these} 2$ procedures for size-fractionating chl a samples revealed that the latter approach resulted in concentrations of chl $a$ in the $>2 \mu \mathrm{m}$ size fraction that were $~ 15 \%$ greater than separation of chl a based on the sequential fractionation approach (data not shown). Chlorophyll (chl) concentrations from 3 (of 230 total) size-fractionated samples fell below the detection limit $\left(0.01 \mu \mathrm{g} \mathrm{chl} \mathrm{l}^{-1}\right.$, defined as 3 times the SD of replicate blank determinations) and hence were excluded from further analyses.

Rates of ${ }^{14} \mathrm{C}$-bicarbonate assimilation were determined from seawater samples collected from the same predawn CTD casts described above. Water was subsampled under subdued light from the CTD rosette bottle into 3 replicate, $500 \mathrm{ml}$ polycarbonate bottles, and the bottles were transferred to a shipboard laboratory van where they were inoculated with approximately $0.05 \mathrm{mCi}$ of $\mathrm{NaH}^{14} \mathrm{CO}_{3}$. Samples were incubated over the full daylight period on a surface-tethered, in situ array (Letelier et al. 1996). At the end of the incubation period, $250 \mu$ laliquots from each sample were placed in $20 \mathrm{ml}$ glass scintillation vials containing $500 \mu \mathrm{l} \beta$-phenylethylamine to determine the total ${ }^{14} \mathrm{C}$ activity in each sample. During the initial period of this study (October 2004 to October 2007), triplicate $500 \mathrm{ml}$ bottles were vacuum-filtered through sequential, $25 \mathrm{~mm}$ diameter, $10 \mu \mathrm{m}$ pore size, polycarbonate filters followed by $25 \mathrm{~mm}$ diameter, $2.0 \mu \mathrm{m}$ pore size, polycarbonate filters. The $<2 \mu \mathrm{m}$ filtrates were retained, and $250 \mathrm{ml}$ of each filtrate was then filtered onto $25 \mathrm{~mm}$ diameter, $0.2 \mu \mathrm{m}$ pore size filters. All filters were stored frozen in $20 \mathrm{ml}$ borosilicate scintillation vials until processed. In the shore-based laboratory, $1 \mathrm{ml}$ of $1 \mathrm{M} \mathrm{HCl}$ was added to each filter to remove adsorbed ${ }^{14} \mathrm{C}$-bicarbonate. After $24 \mathrm{~h}, 10 \mathrm{ml}$ of Ultima Gold scintillation cocktail was added to the scintillation vials and the ${ }^{14} \mathrm{C}$ activity was determined by means of liquid scintillation counting (Packard TRI-Carb 4640).

\section{Size-fractionated P-E experiments}

$P$-E experiments were conducted on 14 HOT cruises to Station ALOHA between October 2007 and December 2009. Water samples for $P$-E experiments were collected from 4 depths $(25,45,75$ and $125 \mathrm{~m})$ in the euphotic zone. Water was subsampled from the CTD rosette bottles into light-shielded, 11 polycarbonate bottles. Approximately $0.3 \mathrm{mCi}$ of ${ }^{14} \mathrm{C}$ bicarbonate was added to $500 \mathrm{ml}$ subsamples of seawater, and $250 \mu \mathrm{l}$ aliquots were removed and placed into $20 \mathrm{ml}$ glass scintillation vials containing $500 \mu \mathrm{l}$ $\beta$-phenylethylamine for determination of the total ${ }^{14} \mathrm{C}$ activity added to each sample. Twenty-four separate aliquots $(15 \mathrm{ml}$ each) of the radiolabeled seawater were transferred to $20 \mathrm{ml}$ borosilicate vials, and these vials were then incubated at in situ temperatures for $2 \mathrm{~h}$ at irradiances varying between 8 and $2049 \mu \mathrm{mol}$ quanta $\mathrm{m}^{-2} \mathrm{~s}^{-1}$ in a photosynthetron apparatus (Lewis \& Smith 1983). The light intensity of each sampling well was measured with a scalar irradiance meter (Biospherical QSL2101). To terminate the incubations, samples were sequentially filtered onto $25 \mathrm{~mm}$ diameter, 2 and $0.2 \mu \mathrm{m}$ pore sized, polycarbonate filters by means of a 12 place vacuum filtration system 
(Millipore). The $2 \mu \mathrm{m}$ filtrates were collected into $15 \mathrm{ml}$ conical centrifuge tubes and filtered onto $0.2 \mu \mathrm{m}$ polycarbonate filters. Filters were stored frozen in $20 \mathrm{ml}$ borosilicate scintillation vials and processed as described above.

Carbon fixation rates for each sample were calculated as:

Carbon fixation $=\left({ }^{14} \mathrm{C}_{\text {filter }} / \mathrm{vol}_{\text {filtered }}\right) /\left({ }^{14} \mathrm{C}_{\text {total }}\right) \times[\mathrm{DIC}] \times$ $12.011 \times 1.06$

where ${ }^{14} \mathrm{C}_{\text {filter }}$ represents the ${ }^{14} \mathrm{C}$ activity on the acidified filters, vol $_{\text {filtered }}$ represents the volume filtered, ${ }^{14} \mathrm{C}_{\text {total }}$ is the total ${ }^{14} \mathrm{C}$ activity in the $250 \mu \mathrm{l}$ aliquot of the radiolabeled seawater, [DIC] is concentration of dissolved inorganic carbon measured by the HOT program at the sampled depth, 12.011 is the molar mass of carbon and 1.06 represents a ${ }^{14} \mathrm{C} /{ }^{12} \mathrm{C}$ isotopic fractionation factor (Steeman-Nielsen 1952). Hourly rates of production were calculated by dividing the daily rates of production by the daylight period of incubation.

\section{Upper ocean habitat characteristics}

Incident solar irradiance (400 to $700 \mathrm{~nm}$ ) was measured on each HOT cruise with a LI-COR LI-1000 cosine collector and data logger. In addition, daily vertical profiles of downwelling PAR were conducted at approximately noon on each HOT cruise with a profiling reflectance radiometer (PRR; Wetlabs). High-sensitivity measurements of nitrate plus nitrite $(\mathrm{N}+\mathrm{N})$ and soluble reactive phosphorus (SRP) were determined as described by Dore \& Karl (1996) and Karl \& Tien (1992), respectively.

\section{Data analysis}

The measured rates of ${ }^{14} \mathrm{C}$-bicarbonate assimilation were used to construct $P-E$ relationships, and the photosynthetic parameters were computed by using the negative exponential formulation described in Platt et al. (1980) as follows:

$$
P=P_{\mathrm{s}}\left[1-\exp \left(-\alpha E / P_{\mathrm{s}}\right)\right] \exp \left(-\beta E / P_{\mathrm{s}}\right)
$$

where $P$ is the photosynthetic carbon fixation rate, $P_{\mathrm{s}}$ is the maximum rate of photosynthesis without photoinhibition, $\alpha$ is the initial slope, $E$ is the light flux, and $\beta$ is the rate of photoinhibition. The maximum rates of ${ }^{14} \mathrm{C}$-bicarbonate assimilation normalized to concentrations of chl $a, P_{\text {max, }}^{\text {chl }}$ were calculated as:

$$
P_{\text {max }}^{\mathrm{chl}}=P^{\mathrm{chl}}{ }_{\mathrm{s}}[\alpha /(\alpha+\beta)][\beta /(\alpha+\beta)]^{\beta / \alpha}
$$

where $P^{\mathrm{chl}}{ }_{\mathrm{s}}$ is the maximum rate of chl a normalized photosynthesis in the absence of photoinhibition (mg $\left.\mathrm{C}(\mathrm{mg} \mathrm{chl})^{-1} \mathrm{~h}^{-1}\right), \alpha$ describes the initial slope of the $P-E$ relationship $\left(\mathrm{mg} \mathrm{C}(\mathrm{mg} \mathrm{chl})^{-1} \mathrm{~h}^{-1}\right)(\mu \mathrm{mol}$ quanta $\left.\mathrm{m}^{-2} \mathrm{~s}^{-1}\right)^{-1}$, and $\beta$ describes the magnitude of photoinhibition of the photosynthetic rate, $\left(\mathrm{mg} \mathrm{C}(\mathrm{mg} \mathrm{chl})^{-1}\right.$ $\mathrm{h}^{-1}$ ) ( $\mu$ mol quanta $\left.\mathrm{m}^{-2} \mathrm{~s}^{-1}\right)^{-1}$. The same $P$-E curve fitting routine was used to estimate $P_{\text {opt }}$ and $P^{\text {chl }}{ }_{\text {opt }}$ terms used to describe optimal rates of photosynthesis (and chlorophyll normalized rates) from the measured vertical profiles of in situ primary productivity. Finally, $E_{k}$, the irradiance required to saturate carbon fixation, an index of photoacclimation, was computed as:

$$
E_{k}=P_{\text {max }}^{\mathrm{chl}} \alpha
$$

Uncertainties associated with the $P-E$ curve-fitting routine were determined and propagated through the subsequent derivations of the $P-E$ parameters (Meyer 1975) as follows:

$$
\begin{aligned}
& \delta_{P_{\max }}=P_{\max } \times \sqrt{ }\left\{\left(\delta_{P_{\mathrm{s}}} / P_{\mathrm{s}}\right)^{2}+\left(\delta_{\alpha} / \alpha\right)^{2}+\left(\delta_{\alpha}{ }^{2}+\delta_{\beta}{ }^{2}\right) /(\alpha+\beta)^{2}\right. \\
& \left.+\left[\left(\delta_{\beta} / \beta\right)^{2}+\left(\delta_{\alpha} / \alpha\right)^{2}\right] \times \beta^{2} / \alpha^{2} \times[\log (\beta / \alpha)+1]^{2}\right\}
\end{aligned}
$$

and

$$
\delta_{E_{k}}=E_{k} \times \sqrt{ }\left[\left(\delta_{P_{\max }} / P_{\max }\right)^{2}+\left(\delta_{\alpha} / \alpha\right)^{2}\right]
$$

Error propagations for $P_{\text {opt }}$ followed the same procedures as $P_{\max }$. Statistical comparisons of photosynthetic parameters between size fractions and among different depths were evaluated with 1-way ANOVA. Relationships between the derived photosynthetic parameters and various environmental properties (temperature, light, nutrients) were examined based on least-squares linear regression analyses.

\section{RESULTS}

\section{Variability in mixing and light}

The depth of the upper ocean mixed layer (based on the 0.125 unit change in potential density during this study from the surface ocean, Levitus 1982) varied between 16 and $124 \mathrm{~m}$, with the upper ocean being most stratified during warm summer months (mixed layer depths between May and October averaged $46 \pm 15 \mathrm{~m}$ [mean $\pm \mathrm{SD}$ ]) and deepening in the winter (averaging $77 \pm 26 \mathrm{~m}$ between November and April). Incident irradiance varied from 12 to $56 \mathrm{~mol}$ quanta $\mathrm{m}^{-2} \mathrm{~d}^{-1}$ during the study period, and the solar flux at the sea surface was elevated in the summer and then decreased in the winter. In the well-lit 
Table 1. Summary of euphotic zone characteristics at Station ALOHA during the study period (2004 to 2009) broadly binned by season. Depicted are median and range (in parentheses) of temperature, downwelling irradiance (photosynthetically active radiation, PAR), percentage downwelling irradiance relative to surface irradiance, nitrate plus nitrite $(\mathrm{N}+\mathrm{N})$ and soluble reactive phosphorus (SRP) at depths where rates of ${ }^{14} \mathrm{C}$-bicarbonate assimilation were measured and photosynthesis-irradiance $(P-E)$ experiments were conducted. BD indicates $\mathrm{N}+\mathrm{N}$ concentration below the detection limit $\left(<2 \mathrm{nmol} \mathrm{l}^{-1}\right)$

\begin{tabular}{|c|c|c|c|c|c|}
\hline $\begin{array}{l}\text { Depth } \\
\text { (m) }\end{array}$ & $\begin{array}{c}\text { Temperature } \\
\left({ }^{\circ} \mathrm{C}\right)\end{array}$ & $\begin{array}{c}\text { PAR } \\
\left.\text { (mol quanta } \mathrm{m}^{-2} \mathrm{~d}^{-1}\right)\end{array}$ & $\begin{array}{l}\text { Irradiance } \\
\qquad(\%)\end{array}$ & $\begin{array}{c}\mathrm{N}+\mathrm{N} \\
\left(\mathrm{nmol} \mathrm{l}^{-1}\right)\end{array}$ & $\begin{array}{c}\mathrm{SRP} \\
\left(\mathrm{nmol} \mathrm{l}^{-1}\right)\end{array}$ \\
\hline \multicolumn{6}{|c|}{ Fall/winter } \\
\hline 5 & $24.1(22.9-26.1)$ & $20.2(9.3-34.4)$ & $80.1(76.9-82.4)$ & $3(\mathrm{BD}-8)$ & $40(8-92)$ \\
\hline 25 & $24.0(22.8-26.1)$ & $8.0(3.9-15.8)$ & $33.2(24.4-37.9)$ & $3(\mathrm{BD}-9)$ & $41(7-76)$ \\
\hline 45 & $23.9(22.7-26.1)$ & $3.4(1.7-7.3)$ & $13.6(9.4-17.5)$ & $3(\mathrm{BD}-14)$ & $35(7-79)$ \\
\hline 75 & $23.7(22.6-25.3)$ & $0.9(0.4-2.3)$ & $3.6(1.9-5.5)$ & 3 (BD-8) & $37(9-72)$ \\
\hline 100 & $22.9(21.8-24.3)$ & $0.3(0.1-0.9)$ & $1.2(0.5-2.1)$ & $16(2-600)$ & 48 (16-99) \\
\hline 125 & $21.8(20.6-23.3)$ & $0.1(0.04-0.3)$ & $0.4(0.1-0.8)$ & $377(3-1019)$ & $94(22-173)$ \\
\hline \multicolumn{6}{|c|}{ Spring/summer } \\
\hline 5 & $26.0(23.8-26.8)$ & $35.1(19.5-44.0)$ & $80.2(75.6-83.0)$ & $4(\mathrm{BD}-8)$ & $53(4-118)$ \\
\hline 25 & $25.9(23.4-26.7)$ & $14.1(7.3-18.4)$ & $33.0(24.6-39.3)$ & $3(\mathrm{BD}-7)$ & $56(4-117)$ \\
\hline 45 & $25.7(22.6-26.7)$ & $5.9(2.8-8.7)$ & $13.8(8.0-18.6)$ & $3(\mathrm{BD}-7)$ & $41(6-95)$ \\
\hline 75 & $23.8(21.6-26.1)$ & $1.6(0.6-2.8)$ & $3.7(1.5-6.1)$ & $3(\mathrm{BD}-9)$ & $26(8-90)$ \\
\hline 100 & $22.7(21.1-24.3)$ & $0.5(0.2-1.1)$ & $1.2(0.4-2.4)$ & $4(2-80)$ & $40(11-84)$ \\
\hline 125 & $22.1(20.0-23.3)$ & $0.2(0.04-0.44)$ & $0.4(0.1-0.9)$ & $70(4-477)$ & $76(25-156)$ \\
\hline
\end{tabular}

upper ocean (0 to $45 \mathrm{~m})$, downwelling irradiance varied $\sim 5$-fold at each of the discrete depths sampled (5, 25 and $45 \mathrm{~m}$ ) over the course of this study. Temporal variability in downwelling irradiance increased with depth, and light fluxes varied as much as 11-fold (0.04 to 0.44 mol quanta $\mathrm{m}^{-2} \mathrm{~d}^{-1}$ ) in the dimly lit region of the lower euphotic zone (125 $\mathrm{m}$, Table 1$)$. Downwelling irradiance was generally $\sim 2$-fold higher in summer months compared with the winter at each of the discrete depths (Table 1). The median light levels at the depths where primary production and chl a concentrations were measured $(5,25,45,75$, 100 and $125 \mathrm{~m}$ ) were $79,30,12,3.2,1.0$ and $0.3 \%$, relative to the surface PAR, respectively. $\mathrm{N}+\mathrm{N}$ concentrations throughout the upper $75 \mathrm{~m}$ did not demonstrate clear differences between the summer and winter (Table 1); however, throughout the dimly lit region of the euphotic zone, $\mathrm{N}+\mathrm{N}$ concentrations increased (on average by 4 - to 5 -fold) in the winter months compared with the summer.

\section{Size-fractionated chl $a$ and in situ ${ }^{14} \mathrm{C}$-bicarbonate assimilation}

Throughout this study, chl a concentrations in the 0.2 to $2 \mu \mathrm{m}$ size fraction consistently exceeded concentrations measured in the $>2 \mu \mathrm{m}$ size class (calculated as the sum of 2 to $10 \mu \mathrm{m}$ and $>10 \mu \mathrm{m} \mathrm{chl} \mathrm{a).} \mathrm{In}$ the well-lit upper ocean (where light flux varied from 1.7 to 44.0 mol quanta $\left.\mathrm{m}^{-2} \mathrm{~d}^{-1}\right), 0.2$ to $2 \mu \mathrm{m} \mathrm{chl} \mathrm{a} \mathrm{con-}$

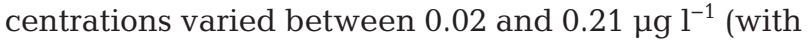
maximum concentrations in July 2005 and minimum concentrations in December 2005). Chl a concentrations in the upper ocean associated with the larger phytoplankton size fraction $(>2 \mu \mathrm{m}$ ) ranged from 0.01 to $0.03 \mathrm{\mu g} \mathrm{l}^{-1}$ (September 2005 and January 2006, respectively) (Fig. 1A). On average, the chl a concentrations in the lower euphotic zone, where light flux varied from 0.04 to 2.8 mol quanta $\mathrm{m}^{-2} \mathrm{~d}^{-1}$, were $\sim 2$-fold greater than concentrations measured in the upper ocean (0 to $45 \mathrm{~m}$, Fig. 1A).

Concentrations of chl $a$ in the $>2 \mu \mathrm{m}$ size class were less variable with depth than concentrations measured in the 0.2 to $2 \mu \mathrm{m}$ size class. On average, concentrations in the $>2 \mu \mathrm{m}$ size class increased $\sim 1.2$-fold into the lower euphotic zone relative to concentrations measured in the well-lit upper ocean (Fig. 1A), while concentrations of chl $a$ in the 0.2 to $2 \mu \mathrm{m}$ plankton size classes increased by $\sim 2$-fold in the lower euphotic zone relative to the well-lit upper ocean (Fig. 1A). The resulting depth-integrated (0 to $125 \mathrm{~m}) \mathrm{chl}$ a concentrations in the 0.2 to $2 \mu \mathrm{m}$ size fraction were 7 to 18 times greater than chl a inventories measured in the $>2 \mu \mathrm{m}$ size fraction (Fig. 2A), and the 0.2 to $2 \mu \mathrm{m}$ size fraction accounted for $91 \%$ $( \pm 2 \%)$ of the total depth integrated (0 to $125 \mathrm{~m}) \mathrm{chl} \mathrm{a}$.

Vertical profiles of ${ }^{14} \mathrm{C}$-bicarbonate assimilation by the $>2 \mu \mathrm{m}$ and 0.2 to $2 \mu \mathrm{m}$ plankton size classes demonstrated dominance of carbon fixation by the smaller phytoplankton size classes at all depths examined (Fig. 1B). Normalization of the ${ }^{14} \mathrm{C}$-bicar- 

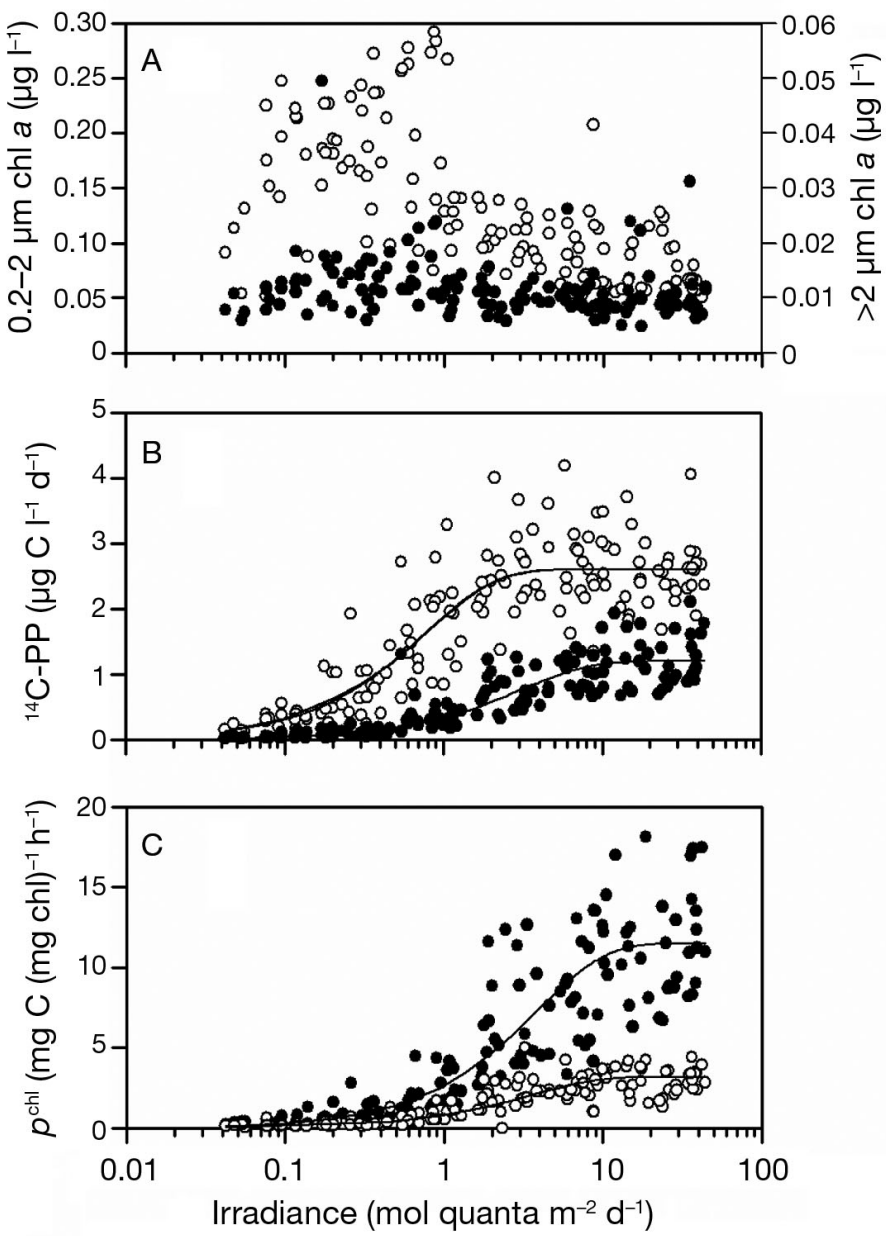

Fig. 1. Size-fractionated (A) chl a concentrations, (B) in situ primary production (PP) and (C) $P^{\text {chl }}$ relative to downwelling photosynthetically active radiation (PAR) (October 2004 to October 2007) where filled circles depict $>2 \mu \mathrm{m}$ size fractions and open circles depict 0.2 to $2 \mu \mathrm{m}$ size fraction. Lines depict least-squares regression fits to the measured rates using the Platt et al. (1980) model. Parameters describing the line fit are maximum rate of carbon fixation $\left(P_{\max }\right)=1.1$, the initial slope $(\alpha)=0.7$, the rate of photoinhibition $(\beta)=0.002, \mathrm{r}^{2}$ $=0.52$ and $\mathrm{p}<0.0001$ for the $>2 \mu \mathrm{m}$ size fraction, and $P_{\max }=$ 2.6, $\alpha=3.2, \beta=0, r^{2}=0.67$ and $p<0.0001$ for the 0.2 to $2 \mu \mathrm{m}$ size fraction (B). Parameters describing the line fit are optimal rate of photosynthesis $\left(P^{\mathrm{chl}}{ }_{\mathrm{opt}}\right)=11.5$, initial slope of the $P^{\text {chl }}$-irradiance relationship $\left(\alpha^{\text {chl }}\right)=3.0, \beta=-0.002, \mathrm{r}^{2}=0.57$ and $\mathrm{p}<0.0001$ for the $>2 \mu \mathrm{m}$ size fraction, and $P^{\mathrm{chl}}{ }_{\mathrm{opt}}=3.2$, $\alpha^{\mathrm{chl}}=0.9, \beta=0.002, \mathrm{r}^{2}=0.55$ and $\mathrm{p}<0.0001$ for the 0.2 to $2 \mu \mathrm{m}$ size fraction (C). Units for $P_{\max }, \alpha, P^{\text {chl }}$ opt and $\alpha^{\text {chl }}$ are $\mu \mathrm{g}$ $\mathrm{C}^{-1} \mathrm{~d}^{-1},\left(\mu \mathrm{g} \mathrm{C} \mathrm{l}^{-1} \mathrm{~d}^{-1}\right)$ (mol quanta $\left.\mathrm{m}^{-2} \mathrm{~d}^{-1}\right)^{-1}, \mathrm{mg} \mathrm{C}(\mathrm{mg}$ $\mathrm{chl})^{-1} \mathrm{~h}^{-1}$, and (mg C (mg chl $\left.)^{-1} \mathrm{~h}^{-1}\right)\left(\mathrm{mol} \text { quanta } \mathrm{m}^{-2} \mathrm{~d}^{-1}\right)^{-1}$, respectively

bonate assimilation to size-fractionated concentrations of chl a $\left(P^{\mathrm{chl}}\right)$ revealed that $P^{\mathrm{chl}}$ in the $>2 \mu \mathrm{m}$ size class always exceeded $P^{\mathrm{chl}}$ derived from the 0.2 to $2 \mu \mathrm{m}$ size class (Fig. 1C). Depth-integrated (0 to $125 \mathrm{~m}$ ) rates of ${ }^{14} \mathrm{C}$-bicarbonate assimilation in the 0.2 to $2 \mu \mathrm{m}$ size fraction ranged between 172 and $348 \mathrm{mg}$
$\mathrm{C} \mathrm{m}^{-2} \mathrm{~d}^{-1}$, and were 1.1- to 5.5-fold greater than in the $>2 \mu \mathrm{m}$ size fraction (Fig. 2B), with the 0.2 to $2 \mu \mathrm{m}$ fraction accounting for $74 \%( \pm 7 \%)$ of the average ${ }^{14} \mathrm{C}$-bicarbonate assimilation in the euphotic zone. In contrast, rates of $P^{\mathrm{chl}}$ (depth-integrated primary production normalized by depth-integrated $\mathrm{chl} a$ ) in the $>2 \mu \mathrm{m}$ size class were 1.7 - to 9-fold greater than $P^{\mathrm{chl}}$ derived from the 0.2 to $2 \mu \mathrm{m}$ size class (Fig. 2C).

Rates of ${ }^{14} \mathrm{C}$-bicarbonate assimilation by both phytoplankton size classes were consistently greatest in the well-lit upper ocean. Measurements of downwelling irradiance and the size-fractionated rates of in situ ${ }^{14} \mathrm{C}$-bicarbonate assimilation were fitted to the Platt et al. (1980) model describing photosynthesis as a function of irradiance (Fig 1B). The resulting relationships suggested that variation in the downwelling light field explained 52 to $57 \%$ and 55 to
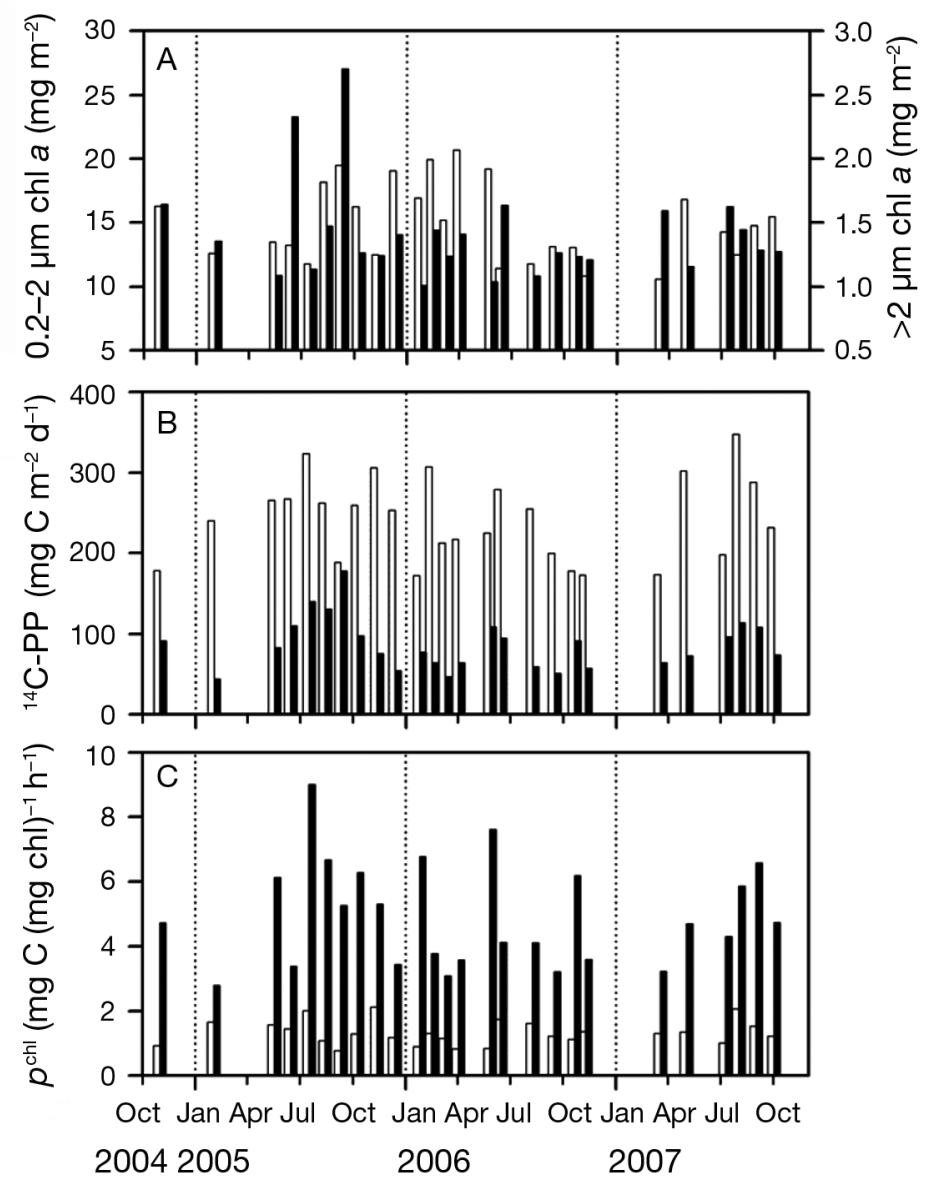

Fig. 2. (A) Depth-integrated (0 to $125 \mathrm{~m}$ ) chl a concentrations, (B) in situ rates of ${ }^{14} \mathrm{C}$-bicarbonate assimilation, and (C) ${ }^{14} \mathrm{C}$-bicarbonate assimilation normalized to chl a concentrations $\left(P^{\mathrm{chl}}\right)$ for the 2 size fractions. PP: primary production. Filled bars represent the $>2 \mu \mathrm{m}$ size fraction and open bars represent the 0.2 to $2 \mu \mathrm{m}$ size fraction 
$67 \%$ of the variability associated with primary production and $P^{\mathrm{chl}}$ for the 0.2 to $2 \mu \mathrm{m}$ and $>2 \mu \mathrm{m}$ size classes, respectively. Further, these analyses indicated that, on average, $P_{\text {opt }}$ and $\alpha$ in the 0.2 to $2 \mu \mathrm{m}$ size fraction were greater than those observed in the $>2 \mu \mathrm{m}$ size fraction (Fig. 1B), but the irradiance required to saturate in situ productivity was lower in the 0.2 to $2 \mu \mathrm{m}$ size fraction $\left(0.8 \mathrm{~mol}\right.$ quanta $\left.\mathrm{m}^{-2} \mathrm{~d}^{-1}\right)$ than in the $>2 \mu \mathrm{m}$ size fraction $\left(1.6 \mathrm{~mol}\right.$ quanta $\mathrm{m}^{-2}$ $\left.\mathrm{d}^{-1}\right)$. After normalization to concentrations of $\mathrm{chl} \mathrm{a}_{\text {, }}$ the in situ $P^{\mathrm{chl}}{ }_{\text {opt }}$ and $\alpha$ were 3 - to 4 -fold greater in the $>2 \mu \mathrm{m}$ size fraction than in the 0.2 to $2 \mu \mathrm{m}$ size fraction (Fig. 1C). In contrast, the derived values of $E_{k}$ from the in situ production rates were similar for the 0.2 to $2 \mu \mathrm{m}$ and $>2 \mu \mathrm{m}$ size fractions $(3.4 \pm 0.7$ and $3.8 \pm 0.5 \mathrm{~mol}$ quanta $\mathrm{m}^{-2} \mathrm{~d}^{-1}$, respectively).

\section{Temporal and vertical variability of $P-E$ derived parameters}

A total of 88 individual $P$ - $E$ curves were conducted and analyzed as part of this study. The Platt et al. (1980) model described 35 to $96 \%$ of the variance in 71 of these relationships (Fig. $3 ; r^{2}=0.35$ to $0.96, p<$ 0.01). Results from the remaining 17 experiments did not demonstrate statistically significant relationships when fitted to the Platt et al. (1980) model ( $p>0.01)$ and thus were excluded from further analyses. In general, the $P$-E relationships demonstrated several consistent patterns: (1) rates of ${ }^{14} \mathrm{C}$-bicarbonate assimilation were dominated by the 0.2 to $2 \mu \mathrm{m}$ plankton size fraction at all depths sampled; (2) the $\alpha$ derived from the $P$ - $E$ relationships of both size fractions were greater in those samples collected from the dimly lit region of the lower euphotic zone compared with samples collected in the well-lit upper ocean; (3) the $E_{k}$ was significantly lower in those samples collected from the dimly lit region of the lower euphotic zone for both size fractions; (4) both phytoplankton size fractions demonstrated photoinhibition in the dimly lit region of the lower euphotic zone where downwelling irradiance decreased to between 0.04 and $0.44 \mathrm{~mol}$ quanta $\mathrm{m}^{-2} \mathrm{~d}^{-1}$, while none of the samples collected from the well-lit upper ocean demonstrated significant photoinhibition ( $\beta \approx 0$; Fig. 3 , Table 2 ).

There were several notable differences in the $P-E$ derived photosynthetic responses among the different phytoplankton size classes, some of which appeared to be depth dependent (Fig. 4). The $P^{\text {chl }}$ max from the 0.2 to $2 \mu \mathrm{m}$ phytoplankton assemblages did not show clear vertical structure; however, $P^{\text {chl }}{ }_{\text {max }}$ derived from the $>2 \mu \mathrm{m}$ size fractions were signifi-
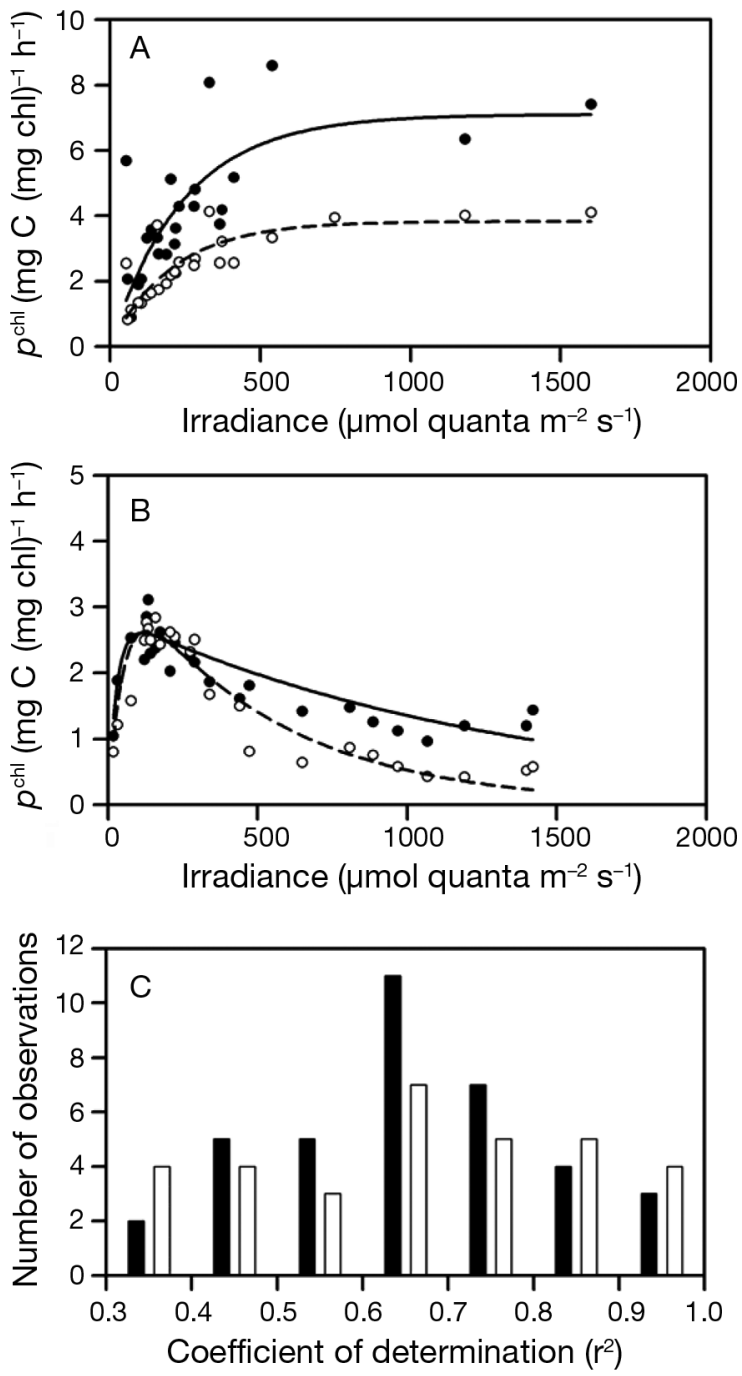

Fig. 3. Photosynthesis-irradiance $(P-E)$ curves from (A) the upper euphotic zone (25 $\mathrm{m}$ ) and (B) the deep euphotic zone $(125 \mathrm{~m})$ at Station ALOHA (December 2009); the $>2 \mu \mathrm{m}$ size fraction is depicted by filled circles and the 0.2 to $2 \mu \mathrm{m}$ size fraction is shown as open circles. (C) Histogram of coefficients of determination $\left(\mathrm{r}^{2}\right)$ derived from least-squares regression analyses of $P-E$ measurements using the Platt et al. (1980) model. Filled bars represent the $>2 \mu \mathrm{m}$ size fraction and open bars represent the 0.2 to $2 \mu \mathrm{m}$ size fraction

cantly lower in the dimly lit region of the euphotic zone than in the upper $75 \mathrm{~m}$ (1-way ANOVA, p < 0.01 ). The average values of $P^{\mathrm{chl}}$ max in the $>2 \mu \mathrm{m}$ size class at 25, 45, 75 and $125 \mathrm{~m}$ were $7.0,6.8,6.5$ and $2.7 \mathrm{mg} \mathrm{C}\left(\mathrm{mg} \mathrm{chl}^{-1} \mathrm{~h}^{-1}\right.$, respectively, and 3.2, 2.2, 2.6 and $2.4 \mathrm{mg} \mathrm{C}(\mathrm{mg} \mathrm{chl})^{-1} \mathrm{~h}^{-1}$, respectively, for the 0.2 to $2 \mu \mathrm{m}$ size class. Although temporally variable, on average in the well-lit upper ocean (25 and $45 \mathrm{~m}$ ) $P^{\text {chl }}{ }_{\text {max }}$ of the $>2 \mu \mathrm{m}$ size class was significantly greater than $P_{\text {max }}^{\text {chl }}$ derived for the 0.2 to $2 \mu \mathrm{m}$ size class (1-way ANOVA, $\mathrm{p}<0.01)$. Moreover, $P^{\mathrm{chl}}$ max of 
Table 2. Summary of photophysiological properties at Station ALOHA (2007 to 2009) derived from photosynthesis-irradiance $(P-E)$ experiments. Depicted are median and range (in parentheses) of $P$ - $E$ properties for 2 size classes of phytoplankton at 25, 45, 75 and $125 \mathrm{~m}$ depths. $P_{\max }$ : maximum rate of carbon fixation; $P_{\text {max }}^{\text {chl }}$ chl a normalized maximum photosynthetic rate; $\alpha$ : initial slope of $P-E_{;} \beta$ : rate of photoinhibition; $E_{k}$ : saturation irradiance. Units for $\alpha$ and $\beta$ are $\left(\mathrm{mg} \mathrm{C}\left(\mathrm{mg} \mathrm{chl}^{-1} \mathrm{~h}^{-1}\right)\right.$ $\left(\mu \mathrm{mol} \text { quanta } \mathrm{m}^{-2} \mathrm{~s}^{-1}\right)^{-1}$

\begin{tabular}{|c|c|c|c|c|c|}
\hline Size class & $\underset{\left(\mu g \mathrm{C}^{-1} \mathrm{~h}^{-1}\right)}{P_{\max }}$ & $\begin{array}{c}P_{\max }^{\mathrm{chl}} \\
\left.\left(\mathrm{mg} \mathrm{C}\left(\mathrm{mg} \mathrm{chl}^{-1}\right)^{-1}\right)^{-1}\right)\end{array}$ & $\alpha$ & $\beta\left(\times 10^{3}\right)$ & $\begin{array}{c}E_{k}(\mu \mathrm{mol} \\
\left.\text { quanta } \mathrm{m}^{-2} \mathrm{~s}^{-1}\right)\end{array}$ \\
\hline \multicolumn{6}{|l|}{$25 \mathrm{~m}$ depth } \\
\hline$>2 \mu \mathrm{m}$ & $0.12(0.06-0.26)$ & $7.2(1.7-14)$ & $0.04(0.01-0.07)$ & $0.4(-2-5)$ & $175(37-319)$ \\
\hline $0.2-2 \mu \mathrm{m}$ & $0.20(0.08-0.26)$ & $3.3(1.9-4.5)$ & $0.03(0.01-0.06)$ & $0.1(-1-4)$ & $124(37-286)$ \\
\hline \multicolumn{6}{|l|}{$45 \mathrm{~m}$ depth } \\
\hline$>2 \mu \mathrm{m}$ & $0.09(0.05-0.34)$ & $5.8(2.5-14.2)$ & $0.02(0.02-0.06)$ & $0.2(-0.8-2)$ & $137(111-235)$ \\
\hline $0.2-2 \mu \mathrm{m}$ & $0.12(0.05-0.25)$ & $2.0(0.9-3.5)$ & $0.02(0.01-0.02)$ & $0.1(0-1)$ & $107(88-178)$ \\
\hline \multicolumn{6}{|l|}{$75 \mathrm{~m}$ depth } \\
\hline$>2 \mu \mathrm{m}$ & $0.14(0.13-0.49)$ & $6.4(2.8-13.4)$ & $0.04(0.03-0.08)$ & $3(1-13)$ & $162(64-253)$ \\
\hline $0.2-2 \mu \mathrm{m}$ & $0.20(0.08-0.51)$ & $2.1(1.8-4.6)$ & $0.02(0.01-0.02)$ & $1(0.1-5)$ & $167(95-262)$ \\
\hline \multicolumn{6}{|c|}{$125 \mathrm{~m}$ depth } \\
\hline$>2 \mu \mathrm{m}$ & $0.06(0.03-0.1)$ & $2.9(1.3-5.9)$ & $0.06(0.03-0.1)$ & $2(0.4-10)$ & $44(25-104)$ \\
\hline $0.2-2 \mu \mathrm{m}$ & $0.19(0.1-0.34)$ & $2.4(1.5-3.7)$ & $0.05(0.02-0.1)$ & $5(1-11)$ & $40(27-111)$ \\
\hline
\end{tabular}

the $>2 \mu \mathrm{m}$ phytoplankton size class varied as much as 8 -fold through time, i.e. 1.7 to $14.2 \mathrm{mg} \mathrm{C} \mathrm{(mg} \mathrm{chl})^{-1}$ $\mathrm{h}^{-1}$, in the well-lit upper ocean. In comparison, downwelling irradiance in the upper ocean at the depths where chl $a$ and primary production were measured (5, 25 and $45 \mathrm{~m})$ varied $\sim 2$-fold during the study period. In the lower regions of the euphotic zone, variability in $P^{\mathrm{chl}}$ max in the $>2 \mu \mathrm{m}$ phytoplankton size class appeared similar to variations in downwelling irradiance (Fig. 4A).

In addition to these differences in $P_{\text {max }}^{\text {chl }}$ on average, $\alpha$ of the 0.2 to $2 \mu \mathrm{m}$ size class varied significantly with depth with the largest values observed in the dimly lit region of the lower euphotic zone (1-way ANOVA, $\mathrm{p}<0.001$; Table 2 ). In contrast, although not statistically different (1-way ANOVA, p > 0.05) $\alpha$ in the $>2 \mu \mathrm{m}$ size class was often greater at deeper depths in the euphotic zone. Temporal and vertical variability in derived values of $E_{k}$ resulted in no significant differences between the 2 phytoplankton size classes at any of the depths sampled (1-way ANOVA, $\mathrm{p}>0.05)$.

Values of $E_{k}$ from both size fractions were significantly lower in the dimly lit region of the lower euphotic zone $(125 \mathrm{~m})$, where downwelling irradiance decreased to 0.04 to 0.44 mol quanta $\mathrm{m}^{-2} \mathrm{~d}^{-1}$, compared with $E_{k}$ values derived from the well-lit upper ocean (1-way ANOVA, p < 0.01). In the well-lit upper ocean ( 0 to $45 \mathrm{~m}$ ), $E_{k}$ values ranged between 37 and $286 \mu \mathrm{mol}$ quanta $\mathrm{m}^{-2} \mathrm{~s}^{-1}$ for the 0.2 to $2 \mu \mathrm{m}$ size class, and 37 and $319 \mu \mathrm{mol}$ quanta $\mathrm{m}^{-2} \mathrm{~s}^{-1}$ for the $>2 \mu \mathrm{m}$ size class. With 2 exceptions, values of $E_{k}$ in both size fractions from the well-lit upper ocean were lower than the measured downwelling irradiance at the depths where samples were collected. The 2 exceptions occurred from samples collected at $45 \mathrm{~m}$ depth in December 2008 and December 2009; on both of these sampling occasions the mixed layer depth exceeded $75 \mathrm{~m}$. In contrast, throughout the lower euphotic zone (75 to $125 \mathrm{~m}$ ), $E_{k}$ ranged between 27 and 262 for the 0.2 to $2 \mu \mathrm{m}$ size class, and between 25 and 253 for the $>2 \mu \mathrm{m}$ size class, which was consistently greater than the measured downwelling irradiance at these depths (Fig. 4B).

Throughout the upper $45 \mathrm{~m}$ of the euphotic zone, rates of $P^{\text {chl }}{ }_{\text {max }}$ derived from the $>2 \mu \mathrm{m}$ plankton size fractions were more temporally variable than those from the 0.2 to $2 \mu \mathrm{m}$ size fraction. For example, at $25 \mathrm{~m}, P^{\mathrm{chl}}$ max for the $>2 \mu \mathrm{m}$ size fraction varied $\sim 8$-fold over the course of this study, while $P^{\mathrm{chl}}$ max in the 0.2 to $2 \mu \mathrm{m}$ plankton size fraction varied $\sim 2$-fold (Fig. $5 \mathrm{~A}$ ). In the lower euphotic zone, temporal variability in $P^{\text {chl }}$ max was generally less pronounced than observed in the upper euphotic zone, with $P^{\text {chl }}$ max at $125 \mathrm{~m}$ varying $\sim 4$ - and 2 -fold, respectively, in the $>2 \mu \mathrm{m}$ and 0.2 to $2 \mu \mathrm{m}$ size fractions (Fig. 5B). In an effort to identify factors influencing the measured and derived photophysiological properties, we examined time-dependent changes in $P^{\mathrm{chl}}{ }_{\max }, E_{k}$ and $\alpha$ relative to several measured environmental properties. Leastsquares linear regression analyses revealed that $E_{k}$ among both size fractions demonstrated dependence on downwelling irradiance in the lower euphotic zone (Model II least-squares linear regressions, >2 $\mu \mathrm{m}: \mathrm{r}^{2}=0.77, \mathrm{p}<0.001 ; 0.2$ to $2 \mu \mathrm{m}: \mathrm{r}^{2}=0.66, \mathrm{p}<$ $0.001) . P_{\max }^{\mathrm{chl}}$ values derived for the $>2 \mu \mathrm{m}$ size frac- 
tion were also related to downwelling irradiance in the lower euphotic zone $\left(\mathrm{r}^{2}=0.35, \mathrm{p}=0.006\right)$. In contrast, $\alpha$ in the 0.2 to $2 \mu \mathrm{m}$ size fraction demonstrated dependence on downwelling irradiance and temperature in the lower euphotic zone $\left(\mathrm{r}^{2}=0.45, \mathrm{p}=0.003\right.$ and $\mathrm{r}^{2}=0.24, \mathrm{p}=0.045$, respectively). Moreover, $\alpha$ in the 0.2 to $2 \mu \mathrm{m}$ size fraction demonstrated a weak but significant relationship to temperature in the lower
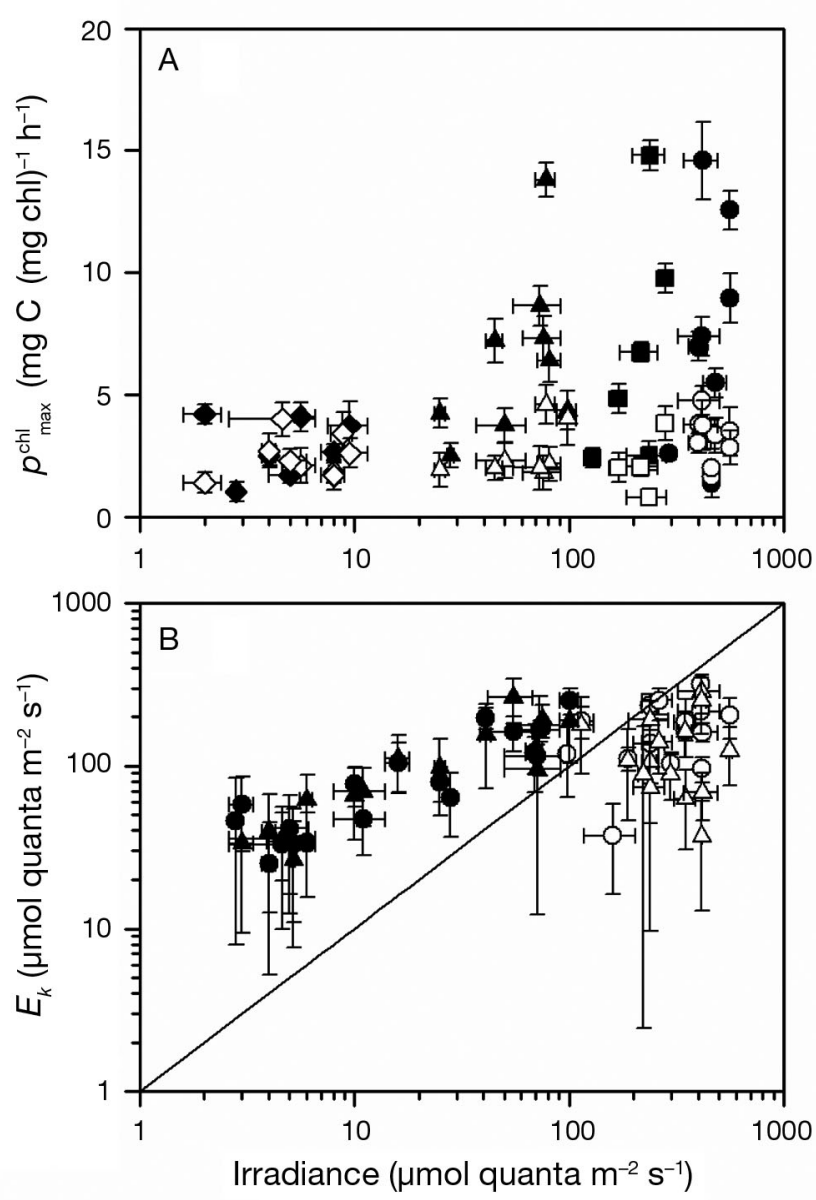

Fig. 4. (A) Relationships between the chl a normalized maximum photosynthetic rate $\left(P_{\text {max }}^{\mathrm{chl}}\right)$ for the 2 phytoplankton size fractions and downwelling irradiance. Symbols represent $P^{\text {chl }}$ max and downwelling irradiance at the 4 depths where photosynthesis-irradiance $(P-E)$ experiments were conducted: 25 (circles), 45 (squares), 75 (triangles) and $125 \mathrm{~m}$ (diamonds). The $>2 \mu \mathrm{m}$ size class is depicted by filled symbols and the 0.2 to $2 \mu \mathrm{m}$ size class is depicted with open symbols; error bars represent $\pm 1 \mathrm{SD}$ of each $P^{\mathrm{chl}}{ }_{\max }$ and downwelling photosynthetically active radiation (PAR) determined for each cruise. (B) Saturation irradiance $\left(E_{k}\right)$ values of 2 size fractions ( $>2 \mu \mathrm{m}$, circles; 0.2 to $2 \mu \mathrm{m}$, triangles) relative to downwelling irradiance measured at approximately noon on each cruise; samples collected from 25 and $45 \mathrm{~m}$ in the euphotic zone are depicted by open symbols, and samples collected from 75 and $125 \mathrm{~m}$ are depicted by filled symbols; error bars represent $\pm 1 \mathrm{SD}$ of each $E_{k}$ and downwelling PAR determined for each cruise; solid line depicts the $1: 1$ ratio

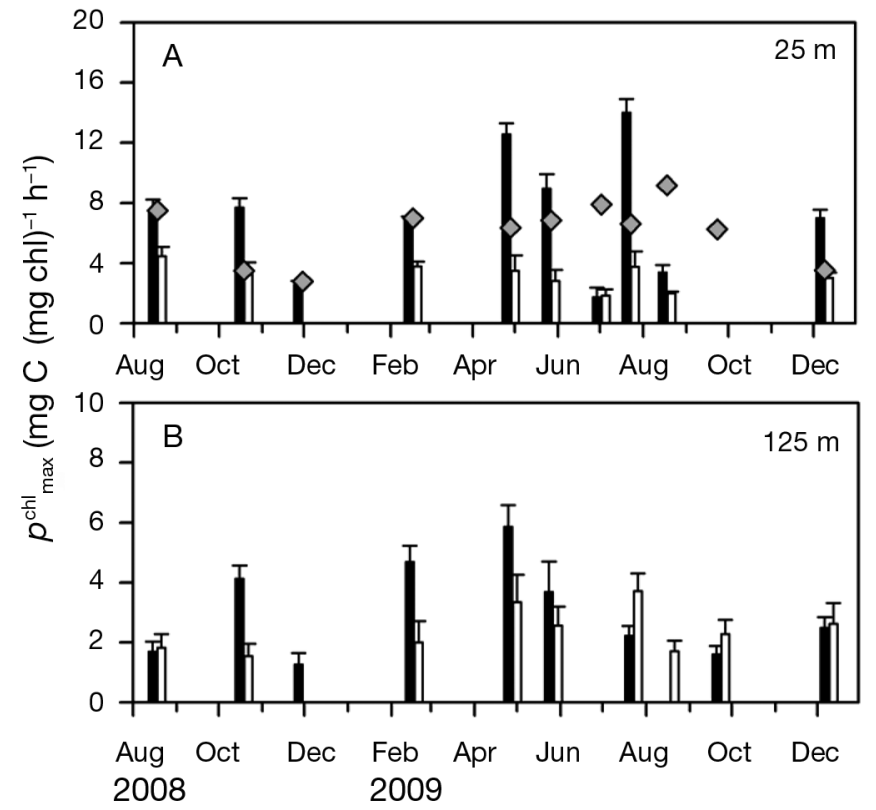

Fig. 5. Time series of the chl a normalized maximum photosynthetic rate $\left(P^{\text {chl }}{ }_{\max }\right)$ of 2 size fractions and in situ $P^{\text {chl }}$ at (A) $25 \mathrm{~m}$ and (B) $125 \mathrm{~m}$. The $>2 \mu \mathrm{m}$ size fraction is depicted by filled bars, and the 0.2 to $2 \mu \mathrm{m}$ size fraction by open bars; $P^{\mathrm{chl}}$ is represented by grey diamonds. Error bars represent SD associated with each $P^{\text {chl }}$ max value

euphotic zone. However, in the upper euphotic zone, least-squares linear regression analyses failed to identify statistically significant relationships between the derived $P$-E parameters and seawater temperature, downwelling PAR or concentrations of nutrients $(\mathrm{N}+\mathrm{N}$ and $\mathrm{SRP})$ (Model II least-squares linear regression analyses, $\mathrm{p}>0.05$ ).

\section{DISCUSSION}

By examining temporal and vertical variations in the responses of ${ }^{14} \mathrm{C}$-bicarbonate assimilation to variations in irradiance, we sought to identify potential differences in the photophysiological behavior of different size classes of phytoplankton in the oligotrophic NPSG. Such differences could exert an important influence on ecosystem productivity and play roles in driving temporal variations in plankton community structure. The results of this study highlighted several features regarding phytoplankton physiology and photosynthetic carbon fixation in the NPSG. Over a nearly $5 \mathrm{yr}$ period of near-monthly sampling at Station ALOHA, we found that chl a normalized rates of carbon fixation by phytoplankton captured onto $2 \mu \mathrm{m}$ filters were always greater than 
the chl a normalized carbon fixation rates measured in the 0.2 to $2 \mu \mathrm{m}$ size class. In addition, in the well-lit upper ocean the $P$-E derived maximum rates of photosynthesis, $P_{\text {max }}^{\text {chl }}$ were significantly greater for the larger $(>2 \mu \mathrm{m})$ phytoplankton size fraction than in the smaller $(0.2$ to $2 \mu \mathrm{m})$ size fraction. Finally, the $P-E$ derived parameters of $P_{\text {max }}^{\mathrm{chl}} \alpha$ and $E_{k}$ were highly variable in time, particularly among the $>2 \mu \mathrm{m}$ size class, suggesting phytoplankton within this size fraction is more sensitive to variations in irradiance than the smaller picophytoplankton.

Our findings that small $(0.2$ to $2 \mu \mathrm{m})$ phytoplankton dominated concentrations of chl $a$ and rates of carbon fixation at Station ALOHA are consistent with previous investigations in this ecosystem (Campbell \& Vaulot 1993, Letelier et al. 1993, Andersen et al. 1996, Campbell et al. 1997). On average, we found that picophytoplankton contributed $\sim 90 \%$ to the 0 to $125 \mathrm{~m}$ chl a standing stocks at Station ALOHA; however, contributions to photosynthesis by these smaller phytoplankton averaged $\sim 70 \%$. Thus, while our study confirmed that smaller phytoplankton $(0.2$ to $2 \mu \mathrm{m}$ ) consistently dominate carbon fixation in this ecosystem, size fractionation of in situ rates of ${ }^{14} \mathrm{C}$ bicarbonate assimilation and the $P$-E derived estimates of $P_{\text {max }}^{\text {chl }}$ both indicate that throughout the high-light, nutrient-poor, upper ocean waters, on a per unit chl a basis, the relatively rare larger phytoplankton (> $2 \mu \mathrm{m})$ appear more efficient at carbon fixation than more dominant, smaller-celled organisms.

The in situ rates of ${ }^{14} \mathrm{C}$-bicarbonate assimilation and $P^{\mathrm{chl}}$ values for both plankton size fractions demonstrated dependence on temporal and vertical variability in downwelling PAR. By fitting these observations to the Platt et al. (1980) model, the derived in situ $P^{\mathrm{chl}}$ opt from the $>2 \mu \mathrm{m}$ size fraction averaged 11.2 $\pm 0.8 \mathrm{mg} \mathrm{C}(\mathrm{mg} \mathrm{chl})^{-1} \mathrm{~h}^{-1}$, while in situ $P^{\mathrm{chl}}{ }_{\text {opt }}$ derived from the 0.2 to $2 \mu \mathrm{m}$ size fraction averaged $3.0 \pm$ $0.2 \mathrm{mg} \mathrm{C}(\mathrm{mg} \mathrm{chl})^{-1} \mathrm{~h}^{-1}$. A similar analysis, which used the HOT in situ ${ }^{14} \mathrm{C}$-bicarbonate assimilation rates derived from samples filtered onto glass fiber filters (nominal pore size, $0.7 \mu \mathrm{m}$ ), revealed that the in situ $P^{\mathrm{chl}}$ opt during our study period (2004 to 2009) was $5.8 \pm 0.2 \mathrm{mg} \mathrm{C}(\mathrm{mg} \mathrm{chl})^{-1} \mathrm{~h}^{-1}$ (data not shown). Letelier et al. (1996) reported $P^{\text {chl }}$ opt values from plankton captured on glass fiber filters ranged between 4.2 and $9.5 \mathrm{mg} \mathrm{C}(\mathrm{mg} \mathrm{chl})^{-1} \mathrm{~h}^{-1}$ at Station ALOHA. Such results suggest that changes in phytoplankton size structure affect $P_{\text {opt }}^{\text {chl }}$ of the bulk community.

Previous investigations of phytoplankton size structure and productivity in other oceanic systems also indicate the dominance of picophytoplankton
(0.2 to $2 \mu \mathrm{m})$ both in terms of biomass and primary production (Li et al. 1983, Magazzu \& Decembrini 1995, Buck et al. 1996, Gasol et al. 1997, Marañón et al. 2001, Ignatiades et al. 2002, Fernandez et al. 2003, Teira et al. 2005, Poulton et al. 2006). Several studies in the tropical and subtropical Atlantic Ocean have reported that the relative contribution of large (>2 $\mu \mathrm{m})$ phytoplankton to chl a was less than their contribution to primary production, implying the $P^{\mathrm{chl}}$ were significantly greater in the $>2 \mu \mathrm{m}$ size phytoplankton than in the $<2 \mu \mathrm{m}$ picoplankton (Marañón et al. 2001, Fernandez et al. 2003, Poulton et al. 2006). Consistent with these reports from other regions, our study in the oligotrophic NPSG revealed elevated rates of $P^{\mathrm{chl}}$ in the $>2 \mu \mathrm{m}$ size phytoplankton, which suggests larger cells in this habitat are more photosynthetically efficient (on a per unit chl a basis) in carbon fixation than picophytoplankton.

Analyses of size-fractionated $P-E$ responses yielded information on time and space variability in euphotic zone photosynthesis and highlighted differences in the photosynthetic behavior of the 2 phytoplankton size fractions examined. For example, consistent with previous studies (Ondrusek et al. 2001, Church et al. 2004), comparison of the $P-E$ derived estimates of $E_{k}$ relative to measured downwelling irradiance indicated that rates of photosynthesis were light saturated throughout the well-lit upper ocean, where PAR flux varied between 128 and $562 \mu \mathrm{mol}$ quanta $\mathrm{m}^{-2} \mathrm{~s}^{-1}$. In this light-saturated region of the upper euphotic zone, $P^{\mathrm{chl}}$ max by the larger phytoplankton size fraction were significantly greater than those observed among the smaller size fraction. In addition, the relatively high temporal variability observed in $\alpha$ suggests that although these larger phytoplankton comprise a relatively small portion of the total biomass of the NPSG, members of this larger size class appear capable of rapid photophysiological acclimation.

Based on information on the intracellular turnover of chl a, Falkowski (1981) estimated a theoretical upper limit for $P^{\text {chl }}{ }_{\text {max }}$ of $25 \mathrm{mg} \mathrm{C}\left(\mathrm{mg} \mathrm{chl}^{-1} \mathrm{~h}^{-1}\right.$. In our study, $P_{\text {max }}^{\text {chl }}$ values ranged between 0.9 and $4.6 \mathrm{mg}$ $\mathrm{C}(\mathrm{mg} \mathrm{chl})^{-1} \mathrm{~h}^{-1}$ for the 0.2 to $2 \mu \mathrm{m}$ size fraction and between 1.2 and $14.2 \mathrm{mg} \mathrm{C}(\mathrm{mg} \mathrm{chl})^{-1} \mathrm{~h}^{-1}$ in the $>2 \mu \mathrm{m}$ size fraction. Several previous studies conducted in regions of the oligotrophic ocean have argued that relatively low rates of $P^{\text {chl }}$ max were a consequence of nutrient-limited plankton growth (Platt et al. 1992, Hood 1995, Marañón \& Holligan 1999). Marañón \& Holligan (1999) examined the $P$-E parameters in the surface waters of the North Atlantic Subtropical Gyre and found that $P^{\mathrm{chl}}$ max values ranged 
between 4 and $7 \mathrm{mg} \mathrm{C}(\mathrm{mg} \mathrm{chl})^{-1} \mathrm{~h}^{-1}$. Those authors observed much greater $P_{\text {max }}^{\mathrm{chl}}$ values in more nutrient-enriched temperate waters and within upwelling regions in the Atlantic Ocean, which suggests nutrient availability plays an important role in controlling variability in $P^{\mathrm{chl}}$ max. Our findings would be consistent with the hypothesis that larger phytoplankton in the NPSG are capable of more rapid growth than the abundant picophytoplankton, but that the biomass and productivity of these larger cells are restricted by the availability of nutrients and possibly grazing.

It is important to note that the relatively small sample volumes $(15 \mathrm{ml})$ used for $P-E$ studies probably results in underrepresentation of less abundant, larger phytoplankton cells and colonies such as chainforming diatoms and Trichodesmium that are known to be important components of the NPSG plankton community. Undersampling of these organisms could contribute to the relatively high variability observed in the photophysiological parameters. Moreover, our separation of chl $a$ and rates of production on the basis of cell size probably reflects the contributions of many different phytoplankton taxonomic groups, so the resulting temporal variability in $P$ - $E$ parameters could reflect compositional changes in phytoplankton community structure within each size fraction rather than physiological changes in any one group.

In addition, several other important caveats need to be considered when using chl a normalized rates of production as proxies for understanding phytoplankton physiology and growth. We did not attempt to constrain variations in phytoplankton C:chl a ratios as part of this study; however, laboratory studies suggest C:chl a ratios can vary more than 10-fold, and changes in this ratio are attributable to various environmental factors that influence phytoplankton life histories, including light, nutrient concentrations and temperature (Goldman 1980, Geider 1987, Geider et al. 1997, MacIntyre et al. 2002). At Station ALOHA vertical profiles indicate chl a concentrations are generally elevated in the lower regions of the euphotic zone; however, this condition appears to derive from increased chl a per cell in this low-light region of the water rather than increases in plankton biomass (Campbell \& Vaulot 1993, Campbell et al. 1997, Karl et al. 2002). Our own examination of HOT program, flow cytometrically derived picoplankton abundances (data not shown) indicated that abundances of Prochlorococcus and Synechococcus often peak in the upper euphotic zone rather than at the depths where chlorophyll concentrations are elevated. Similarly, seasonal changes in light can alter chl a without concomitant changes in biomass; Winn et al. (1995) found that the fluorescence per unit cell of Prochlorococcus populations dwelling in the upper euphotic zone at Station ALOHA varied 2-fold between winter and summer.

When normalized to chl $a$, larger cells appeared to be more productive than smaller cells, which could also reflect uncertainties associated with the use of the ${ }^{14} \mathrm{C}$-methodology to measure carbon fixation. In ecosystems where microbial food webs impose tight coupling on growth and removal of picoplanktonic cells, turnover of photosynthetically fixed carbon by small cells would be expected to be rapid, thereby complicating whether the measurement provides an estimate closer to gross or net production (Smith et al. 1984, Williams \& Lefèvre 1996). Further, if picophytoplankton growth results in a larger fraction of photosynthetically fixed carbon passing to the dissolved organic carbon pool compared with larger cells (Bjørnsen 1988), filtration-based approaches would underestimate carbon fixation by these small cells. In addition, if small cells demonstrate greater per cell rates of respiration than observed in larger cells (Laws 1975, Banse 1976, Tang \& Peters 1995), the ${ }^{14} \mathrm{C}$ methodology used in the present study might more closely approximate net photosynthesis for these smaller cells, but approach gross photosynthesis by the larger phytoplankton.

Comparison of our $P$-E derived values of $E_{k}$ to measured downwelling PAR in the lower euphotic zone indicated that the photosynthetic production by both phytoplankton size fractions was light limited when PAR fluxes were less than $\sim 3$ mol quanta $\mathrm{m}^{-2} \mathrm{~d}^{-1}$. At these subsaturating light intensities, rates of carbon fixation by both size fractions demonstrated a near linear response to changes in irradiance. Moreover, the slope of this response $(\alpha)$ was comparable between both size fractions. In the dimly lit region of the lower euphotic zone, both $P^{\mathrm{chl}}{ }_{\max }$ and $E_{\mathrm{k}}$ of the larger size fraction were significantly lower than observed in the well-lit regions of the euphotic zone. Such results are consistent with physiological acclimations to growth at low irradiance (MacIntyre et al. 2002), whereby phytoplankton can increase the size of the light-harvesting antennae and/or increase the number of photosynthetic reaction centers (Falkowski \& Owens 1980, Dubinsky et al. 1986). Laboratory studies indicate that variability in the electron turnover rate of the photosynthetic unit (PSU) partly controls $P^{\text {chl }}{ }_{\max }$ and $E_{k}$ (Moore et al. 2006), with the number of photosynthetic reaction centers inversely related to the electron turnover rate of the PSU (Sukenik et al. 1987). As a result, the observed decrease in $P_{\text {max }}^{\text {chl }}$ and $E_{k}$ in the lower euphotic zone 
in the present study may reflect acclimation through changes to the number of reaction centers, rather than increases in the size of the light harvesting antennae.

We also used linear regression analyses in an attempt to identify prominent environmental factors influencing photosynthesis at Station ALOHA. These analyses revealed that $E_{k}$ in the lower euphotic zone was significantly correlated with downwelling irradiance, suggesting that these light-limited cells react rapidly to in situ changes in irradiance. However, our results also indicate that the 2 size-fractions of phytoplankton appear to have different strategies of photoacclimation. In the larger size fraction, $P^{\text {chl }}$ max was significantly correlated with downwelling irradiance while $\alpha$ was not significantly correlated with downwelling irradiance, suggesting that the larger phytoplankton adjust the turnover rate of photosynthetic electron transport instead of varying the functional absorption cross-section of photosystem II $\left(\sigma_{\mathrm{PSII}}\right)$ during photoacclimation (Falkowski \& Raven 2007). In contrast, $\alpha$ in the smaller size fraction was significantly correlated with downwelling irradiance while no significant correlation was found between $P^{\text {chl }}$ max and downwelling irradiance; such results may indicate that picophytoplankton are better able to adjust $\sigma_{\mathrm{PSII}}$ in response to changes in irradiance.

Our results indicated that the initial slope $\alpha$ in the $<2 \mu \mathrm{m}$ size class displays significant vertical variations, while $\alpha$ of the $>2 \mu \mathrm{m}$ size class is more constant with depth. Such results are consistent with laboratory studies by MacIntyre et al. (2002), who found that $\alpha$ in many microalgae (mostly $>2 \mu \mathrm{m}$ ) demonstrated little $(<20 \%)$ phenotypic variability; in contrast, $\alpha$ among cyanobacteria $(<2 \mu \mathrm{m})$ tended to decline with increasing irradiance. Those authors attribute such changes to plasticity in the phycobiliprotein to chl a ratio. The initial slope $\alpha$ is proportional to the chl a specific light absorption coefficient $\left(a^{\mathrm{chl}}\right)$, which varies among species owing to different pigment compositions and packaging effects. Since phycobiliproteins dominate light absorption in the cyanobacteria, and phycobiliprotein to $\mathrm{chl}$ a ratios decrease with increasing irradiance (Kana et al. 1988, Moore et al. 1995), $a^{\text {chl }}$ in the cyanobacteria would be expected to decline with increasing irradiance. Thus, the observed increase in $\alpha$ in the 0.2 to $2 \mu \mathrm{m}$ size fraction in the lower euphotic zone could be explained by higher phycobiliprotein to chl $a$ ratios among the picocyanobacteria, which dominate the phytoplankton community at Station ALOHA. Moreover, depth-dependent changes in phytoplankton community structure, such as those accompany- ing the transition between vertically separated and physiologically distinct ecotypes of Prochlorococcus (Moore et al. 1995, Malmstrom et al. 2010), could also control the observed vertical differences in $\alpha$.

In conclusion, our research suggests that different size classes of phytoplankton demonstrate significant temporal and vertical variability in photophysiology in the oligotrophic NPSG. Our findings revealed large variability in photosynthesis associated with larger phytoplankton assemblages, which provide potential insight into processes controlling the formation of large-celled phytoplankton blooms in the NPSG (White et al. 2007, Dore et al. 2008, Fong et al. 2008, Wilson et al. 2008). However, the specific factors controlling variability in the efficiency of carbon fixation remain unclear, as do the mechanisms that permit larger sized phytoplankton cells to accumulate during summertime bloom events. Future studies focused on defining processes that underlie the apparent decoupling in cell removal (e.g. predation, sinking or viral attack) from those that enhance phytoplankton growth and the efficiency of carbon fixation would help lend additional mechanistic insight into the dynamics underlying observations from this study.

Acknowledgements. We thank the Hawaii Ocean Timeseries (HOT) program scientists and staff and the crew members of RV 'Kilo Moana' and RV 'Ka'imikai-O-Kanaloa' for support in the field and in the laboratory. The comments of 3 anonymous reviewers and journal editor Graham Savidge improved the manuscript. This work was funded by the U.S. National Science Foundation with grants to the HOT program (OCE09-26766) and the Center for Microbial Oceanography: Research and Education (C-MORE; EF0424599) and by the Gordon and Betty Moore Foundation (to D.M.K.).

\section{LITERATURE CITED}

Andersen RA, Bidigare RR, Keller MD, Latasa M (1996) A comparison of HPLC pigment signatures and electron microscopic observations for oligotrophic waters of the North Atlantic and Pacific Oceans. Deep-Sea Res II 43: 517-537

Banse K (1976) Rates of growth, respiration and photosynthesis of unicellular algae as related to cell size-a review. J Phycol 12:135-140

> Behrenfeld MJ, Falkowski PG (1997) Photosynthetic rates derived from satellite-based chlorophyll concentration. Limnol Oceanogr 42:1-20

Behrenfeld MJ, Boss E, Siegel DA, Shea DM (2005) Carbonbased ocean productivity and phytoplankton physiology from space. Global Biogeochem Cycles 19. doi:10.1029/ 2004GB002299

Bidigare RR, Prézelin BB, Smith RC (1992) Bio-optical models and the problems of scaling. In: Falkowski PG (ed) Primary productivity and biogeochemical cycles in the 
sea. Plenum Press, New York, NY, p 175-212

Bjørnsen PK (1988) Phytoplankton exudation of organic matter: Why do healthy cells do it? Limnol Oceanogr 33: 151-154

> Buck KR, Chavez FP, Campbell L (1996) Basin-wide distributions of living carbon components and the inverted trophic pyramid of the central gyre of the North Atlantic Ocean, summer 1993. Aquat Microb Ecol 10:283-298

> Campbell L, Vaulot D (1993) Photosynthetic picoplankton community structure in the subtropical North Pacific Ocean near Hawaii (station ALOHA). Deep-Sea Res I 40: 2043-2060

> Campbell L, Liu H, Nolla HA, Vaulot D (1997) Annual variability of phytoplankton and bacteria in the subtropical North Pacific Ocean at station ALOHA during the 1991-1994 ENSO event. Deep-Sea Res I 44:167-192

> Church MJ, Ducklow HW, Karl DM (2004) Light-dependence of ${ }^{3} \mathrm{H}$-leucine incorporation in the oligotrophic North Pacific Ocean. Appl Environ Microbiol 70: 4079-4087

> Church MJ, Mahaffey C, Letelier RM, Lukas R, Zehr JP, Karl DM (2009) Physical forcing of nitrogen fixation and diazotroph community structure in the North Pacific subtropical gyre. Global Biogeochem Cycles 23. doi: 10.1029/2008GB003418

Corno G, Letelier RM, Abbott MR, Karl DM (2008) Temporal and vertical variability in photosynthesis in the North Pacific Subtropical Gyre. Limnol Oceanogr 53: 1252-1265

Cullen JJ (1990) On models of growth and photosynthesis in phytoplankton. Deep-Sea Res I 37:667-683

Cullen JJ, Lewis MR, Davis CO, Barber RT (1992) Photosynthetic characteristics and estimated growth rates indicate grazing is the approximate control of primary production in the equatorial Pacific. J Geophys Res 97:639-654

> Dore JE, Karl DM (1996) Nitrite distributions and dynamics at Station ALOHA. Deep-Sea Res II 43:385-402

> Dore JE, Letelier RM, Church MJ, Lukas R, Karl DM (2008) Summer phytoplankton blooms in the oligotrophic North Pacific Subtropical Gyre: historical perspective and recent observations. Prog Oceanogr 76:2-38

Dubinsky Z, Falkowski PG, Wyman K (1986) Light harvesting and utilization by phytoplankton. Plant Cell Physiol 27:1335-1349

Eppley RW (1972) Temperature and phytoplankton growth in the sea. Fish Bull 70:1063-1085

Falkowski PG (1981) Light-shade adaptation and assimilation numbers. J Plankton Res 3:203-216

Falkowski PG, Owens TG (1980) Light-shade adaptation: two strategies in marine phytoplankton. Plant Physiol 66: 592-595

Falkowski PG, Raven JA (2007) Aquatic photosynthesis. Princeton University Press, Princeton, NJ

Falkowski PG, Barber RT, Smetacek V (1998) Biogeochemical controls and feedbacks on ocean primary production. Science 281:200-206

Fernandez E, Marañón E, Moran XAG, Serret P (2003) Potential causes for the unequal contribution of picophytoplankton to total biomass and productivity in oligotrophic waters. Mar Ecol Prog Ser 254:101-109

- Field CB, Behrenfeld MJ, Randerson JT, Falkowski P (1998) Primary production of the biosphere: integrating terrestrial and oceanic components. Science 281:237-240

Fong AA, Karl DM, Lukas R, Letelier RM, Zehr JP, Church MJ (2008) Nitrogen fixation in an anticyclonic eddy in the oligotrophic North Pacific Ocean. ISME J 2:663-676

Gasol JM, del Giorgio PA, Duarte CM (1997) Biomass distribution in marine planktonic communities. Limnol Oceanogr 42:1353-1363

Geider RJ (1987) Light and temperature dependence of the carbon to chlorophyll ratio in microalgae and cyanobacteria: implications for physiology and growth of phytoplankton. New Phytol 106:1-34

Geider RJ, MacIntyre HL, Kana TM (1997) Dynamic model of phytoplankton growth and acclimation: responses of the balanced growth rate and the chlorophyll a:carbon ratio to light, nutrient-limitation and temperature. Mar Ecol Prog Ser 148:187-200

Goebel NL, Kremer JN (2007) Temporal and spatial variability of photosynthetic parameters and community respiration in Long Island Sound. Mar Ecol Prog Ser 329:23-42

Goldman JC (1980) Physiological processes, nutrient availability and the concept of relative growth rate in marine phytoplankton ecology. In: Falkowski PG (ed) Primary productivity in the sea. Plenum Press, New York, NY, p 179-194

Harrison WG, Platt T (1980) Variations in assimilation number of coastal marine phytoplankton: effects of environmental co-variates. J Plankton Res 2:249-260

> Hood RR (1995) Light response of phytoplankton in the South Atlantic Ocean: interpretation of observations and application to remote sensing. J Geophys Res 100: 10927-10942

Ignatiades L, Psarra S, Zervakis V, Pagou K, Souvermezoglou E, Assimakopoulou G, Gotsis-Skretas O (2002) Phytoplankton size-based dynamics in the Aegean Sea (Eastern Mediterranean). J Mar Syst 36:11-28

> Isada T, Kuwata A, Saito H, Ono T, Ishii M, YoshikawaInoue H, Suzuki K (2009) Photosynthetic features and primary productivity of phytoplankton in the Oyashio and Kuroshio-Oyashio transition regions of the northwest Pacific. J Plankton Res 31:1009-1025

> Jassby AD, Platt T (1976) Mathematical formulation of the relationship between photosynthesis and light for phytoplankton. Limnol Oceanogr 21:540-547

> Kana TM, Glibert PM, Goericke R, Welschmeyer NA (1988) Zeaxanthin and $\beta$-carotene in Synechococcus WH7803 respond differently to irradiance. Limnol Oceanogr 33: 1623-1627

Karl DM, Tien G (1992) MAGIC: a sensitive and precise method for measuring dissolved phosphorus in aquatic environments. Limnol Oceanogr 37:105-116

> Karl DM, Christian JR, Dore JE, Hebel DV, Letelier RM, Tupas LM, Winn CD (1996) Seasonal and interannual variability in primary production and particle flux at Station ALOHA. Deep-Sea Res II 43:539-568

Karl DM, Bidigare RR, Letelier RM (2001) Long-term changes in plankton community structure and productivity in the North Pacific Subtropical Gyre: the domain shift hypothesis. Deep-Sea Res II 48:1449-1470

Karl DM, Bidigare RR, Letelier RM (2002) Sustained and aperiodic variability in organic matter production and phototrophic microbial community structure in the North Pacific Subtropical Gyre. In: Williams PJleB, Thomas DN, Reynolds CS (eds) Phytoplankton productivity and carbon assimilation in marine and freshwater ecosystems. Blackwell, London, p 222-264

$>$ Laws EA (1975) The importance of respiration losses in controlling the size distribution of marine phytoplankton. Ecology 56:419-426 
Letelier RM, Bidigare RR, Hebel DV, Ondrusek M, Winn CD, Karl DM (1993) Temporal variability of phytoplankton community structure based on pigment analysis. Limnol Oceanogr 38:1420-1437

Letelier RM, Dore E, Winn CD, Karl DM (1996) Seasonal and interannual variations in autotrophic carbon assimilation at Station ALOHA. Deep-Sea Res II 43:467-490

> Letelier RM, Karl DM, Abbott MR, Bidigare RR (2004) Light driven seasonal patterns of chlorophyll and nitrate in the lower euphotic zone of the North Pacific Subtropical Gyre. Limnol Oceanogr 49:508-519

Levitus S (1982) Climatological atlas of the World Ocean. NOAA Professional Paper 13. National Oceanic and Atmospheric Administration, Rockville, MD

> Lewis MR, Smith JC (1983) A small volume, short-incubation-time method for measurement of photosynthesis as a function of incident irradiance. Mar Ecol Prog Ser 13: 99-102

Li WKW, Subba-Rao DV, Harrison WG, Smith JC, Cullen JJ, Irwin B, Platt T (1983) Autotrophic picoplankton in the tropical ocean. Science 219:292-295

> Longhurst A, Sathyendranath S, Platt T, Caverhill C (1995) An estimate of global primary production in the ocean from satellite radiometer data. J Plankton Res 17: 1245-1271

MacIntyre HL, Kana T, Anning T, Geider RJ (2002) Photoacclimation of photosynthesis irradiance response curves and photosynthetic pigments in microalgae and cyanobacteria. J Phycol 38:17-38

> Magazzu G, Decembrini F (1995) Primary production, biomass and abundance of phototrophic picoplankton in the Mediterranean Sea: a review. Aquat Microb Ecol 9: 97-104

Malmstrom RR, Coe A, Kettler GC, Martiny AC, Frias-Lopez J, Zinser ER, Chisholm SW (2010) Temporal dynamics of Prochlorococcus ecotypes in the Atlantic and Pacific Oceans. ISME J 4:1252-1264

> Marañón E, Holligan PM (1999) Photosynthetic parameters of phytoplankton from $50^{\circ} \mathrm{N}$ to $50^{\circ} \mathrm{S}$ in the Atlantic Ocean. Mar Ecol Prog Ser 176:191-203

> Marañón E, Holligan PM, Barciela R, González N, Mouriño B, Pazó MJ, Varela M (2001) Patterns of phytoplankton size structure and productivity in contrasting open-ocean environments. Mar Ecol Prog Ser 216:43-56

McAndrew PM, Bidigare RR, Karl DM (2008) Primary production and implications for metabolic balance in Hawaiian lee eddies. Deep-Sea Res II 55:1300-1309

Meyer SL (1975) Data analysis for scientists and engineers. John Wiley and Sons, New York, NY

> Moore LR, Goericke R, Chisholm SW (1995) Comparative physiology of Synechococcus and Prochlorococcus: influence of light and temperature on growth, pigments, fluorescence and absorptive properties. Mar Ecol Prog Ser 116:259-275

Moore CM, Suggett DJ, Hickman AE, Kim YN and others (2006) Phytoplankton photoacclimation and photoadaptation in response to environmental gradients in a shelf sea. Limnol Oceanogr 51:936-949

Ondrusek ME, Bidigare RR, Waters K, Karl DM (2001) A predictive model for estimating rates of primary produc-

Editorial responsibility: Graham Savidge,

Portaferry, UK tion in the subtropical North Pacific Ocean. Deep-Sea Res II 48:1837-1863

> Platt T, Sathyendranath S (1993) Estimators of primary production for interpretation of remotely sensed data on ocean color. J Geophys Res 98:14561-14576

Platt T, Gallegos CL, Harrison WG (1980) Photoinhibition of photosynthesis in natural assemblages of marine phytoplankton. J Mar Res 38:687-701

Platt T, Harrison WG, Irwin B, Horne EP, Gallegos CL (1982) Photosynthesis and photoadaptation of marine phytoplankton in the arctic. Deep-Sea Res A 29:1159-1170

Platt T, Sathyendranath S, Ulloa O, Harrison WG, Hoepffner N, Goes J (1992) Nutrient control of phytoplankton photosynthesis in the Western North Atlantic. Nature 356: $229-231$

Poulton AJ, Holligan PM, Hickman A, Kim YN and others (2006) Phytoplankton carbon fixation, chlorophyll-biomass and diagnostic pigments in the Atlantic Ocean. Deep-Sea Res II 53:1593-1610

Sakshaug E, Holm-Hansen O (1986) Photoadaptation in Antarctic phytoplankton: variations in growth rate, chemical composition and $P$ versus $I$ curves. J Plankton Res 8:459-473

Smith REH, Geider RJ, Platt T (1984) Microplankton productivity in the oligotrophic ocean. Nature 311:252-254

Steeman-Nielsen E (1952) The use of radio-active carbon $\left({ }^{14} \mathrm{C}\right)$ for measuring organic carbon production in the sea. J Cons Int Explor Mer 18:117-140

Strzepek RF, Harrison PJ (2004) Photosynthetic architecture differs in coastal and oceanic diatoms. Nature 431: 689-692

Sukenik A, Benne J, Falkowski PG (1987) Light-saturated photosynthesis-limitation by electron transport or carbon fixation? Biochim Biophys Acta 891:205-215

Sverdrup HU, Johnson MW, Fleming RH (1946) The oceans, their physics, chemistry and general biology. PrenticeHall, New York, NY

Tang EPY, Peters RH (1995) The allometry of algal respiration. J Plankton Res 17:303-315

> Teira E, Mouriño B, Marañón E, Pérez PV and others (2005) Variability of chlorophyll and primary production in the Eastern North Atlantic Subtropical Gyre: potential factors affecting phytoplankton activity. Deep-Sea Res I 52: 569-588

White AE, Spitz YH, Letelier RM (2007) What factors are driving summer phytoplankton blooms in the North Pacific Subtropical Gyre? J Geophys Res 112. doi:10.1029/ 2007JC004129

Williams PJleB, Lefèvre D (1996) Algal ${ }^{14} \mathrm{C}$ and total carbon metabolisms. 1. Models to account for the physiological processes of respiration and recycling. J Plankton Res 18: 1941-1959

> Wilson C, Villareal TA, Maximenko N, Bograd SJ, Montoya JP, Schoenbaechler CA (2008) Biological and physical forcings of late summer chlorophyll blooms at 30 degrees $\mathrm{N}$ in the oligotrophic Pacific. J Mar Syst 69:164-176

Winn CD, Campbell L, Christian JR, Letelier RM and others (1995) Seasonal variability in the phytoplankton community of the North Pacific Subtropical Gyre. Global Biogeochem Cycles 9:605-620 doi:10.1029/95GBO2149

Submitted: February 4, 2011; Accepted: August 14, 2011 Proofs received from author(s): October 15, 2011 